\title{
Understory host plant and insect gall diversity changes across topographic habitats differing in nutrient and water stress in the Brazilian Amazon rainforest
}

\author{
Genimar Rebouças JULIÃO ${ }^{1,2}$, Emmanuel Duarte ALMADA ${ }^{3,4^{*}}$, Flávia Regina Capellotto COSTA ${ }^{1}$, \\ Marco Antônio Alves CARNEIRO5, G. Wilson FERNANDES 3,6 \\ ${ }^{1}$ Coordenação de Biodiversidade - COBIO, Instituto Nacional de Pesquisas da Amazônia - INPA, Av. André Araújo 2936, Petrópolis, 69060-001 Manaus, Amazonas, Brazil. \\ ${ }^{2}$ Laboratório de Entomologia, Fiocruz Rondônia - Fundação Oswaldo Cruz, Rua da Beira 7671, Lagoa, 76812-245 Porto Velho, Rondônia, Brazil. \\ ${ }^{3}$ Laboratório de Ecologia Evolutiva e Biodiversidade/Departamento de Biologia Geral, CP 486, Instituto de Ciências Biológicas, Universidade Federal de Minas Gerais/UFMG, \\ 30161-970 Belo Horizonte, Minas Gerais, Brazil. \\ ${ }^{4}$ Laboratório de Estudos Bioculturais, Departamento de Ciências Biológicas, Universidade do Estado de Minas Gerais, 32400-000 Ibirité, Minas Gerais, Brazil. \\ ${ }^{5}$ Laboratório de Entomologia Ecológica, Departamento de Biodiversidade, Evolução e Meio Ambiente/DEBIO, Instituto de Ciências Exatas e Biológicas, Universidade Federal de \\ Ouro Preto, 35400-000 Ouro Preto, Minas Gerais, Brazil. \\ ${ }^{6}$ Department of Biology, Stanford University, 94305 Stanford, California, USA. \\ * Corresponding author: almadaceae@gmail.com
}

\begin{abstract}
Topographic gradients in terra firme forests are associated with pronounced changes in soil texture, soil nutrients and distance to the water-table, thereby creating different hydric and nutritional conditions for plants and their associated herbivore community. The aim of this study was to investigate galling species and host plant richness and gall species composition across topographic habitats differing in nutrient and water stress in the Brazilian Amazon rainforest. Nineteen $250 \times 3 \mathrm{~m}$ plots were randomly sampled in the valley, slope, plateau-slope transition, and plateau habitats in terra firme forests. All individual dicotyledonous plants 1 to 3 meters high were examined for the presence of insect galls. Galling species and host plant richness differed significantly among the studied habitats and were higher in slope habitats (drier habitats), as expected. More humid areas (valleys) showed the lowest richness of galling species, and a lower number of understory host plants. PERMANOVA and PERMDISP results demonstrated that the gall species composition differed significantly in the valley, slope, plateau-slope transition, and plateau areas. However, these structural differences in species composition could be due to unequal dispersion of variability among forest habitats. Our data suggested that spatial heterogeneity, such as a mosaic of local water status and nutrient availability resulting from the topographic conditions, can affect host plants and their associated galling insects.
\end{abstract}

KEYWORDS: habitat stress, soil nutrients, species diversity, terra firme forest, topographic gradient

\section{Riqueza de insetos galhadores associados a habitats de sub-bosque com diferentes topografias e níveis de estresse hídrico e nutricional em uma floresta da Amazônia Central, Brasil}

\section{RESUMO}

As variaçóes topográficas encontradas nas florestas de terra firme são acompanhadas por fortes mudanças no conteúdo de argila e concentração de nutrientes do solo, criando, portanto, diferentes condiçóes hídricas e nutricionais para plantas e as comunidades de herbívoros associadas. O objetivo do presente estudo foi avaliar a riqueza e composição de espécies de insetos galhadores e suas plantas hospedeiras ao longo de um gradiente topográfico com habitats que diferem quanto ao estresse hídrico e nutricional. Dezenove parcelas de 250 × $3 \mathrm{~m}$ foram estabelecidos aleatoriamente em habitats de vertente, platô, transição platô-vertente e baixio, claramente distintos em áreas de terra firme. Todas as dicotiledôneas com 1 a 3 metros de altura foram examinadas quanto à presença de galhas de insetos. As galhas encontradas foram coletadas e insetos galhadores foram classificados em morfoespécies. A riqueza de galhadores e de plantas hospedeiras diferiram significativamente entre os habitats estudados, e como esperado, foi maior no habitat de vertente. As áreas mais úmidas (baixios) apresentaram menor riqueza de plantas hospedeiras no sub-bosque e, conseqüentemente, um número menor de espécies de galhadores. Os resultados das análises de PERMANOVA e PERMDISP demonstraram que a composição da espécie de insetos galhadores variou significativamente entre as áreas de floresta de terra firme. No entanto, essas diferenças estruturais na composição das espécies podem ser devidas à dispersão desigual da variabilidade entre os habitats. Nossos dados sugerem que a heterogeneidade espacial, tal como o mosaico de status hídrico e nutricional do solo associado às condiçóes topográficas, pode afetar plantas hospedeiras e insetos galhadores associados.

PALAVRAS-CHAVE: diversidade de espécies, estresse higrotérmico, floresta de terra firme, gradiente topográfico, nutrientes do solo 


\section{INTRODUCTION}

The patterns of richness of galling insect species have been widely studied over the last few decades (e.g., Mendonça 2001; Cuevas-Reyes et al. 2003; Fernandes and Santos 2014). This herbivore guild attains its maximum richness in hygrothermally (low humidity and high temperature) and nutrient stressed habitats, and is usually associated with sclerophyllous vegetation (Fernandes and Price 1988, 1992). This pattern has been shown to be global, with higher richness at intermediate latitudes where sclerophyllous vegetation prevails $\left(23^{\circ}\right.$ to $45^{\circ}$ north or south of the Equator) (Price et al. 1998; Julião et al. 2005; 2014a,b).

Although little progress has been made towards an understanding of the causes of these patterns, some mechanisms have been proposed. Fernandes and Price (1992) and Ribeiro-Mendes et al. (2002) suggested that higher survival rates in xeric habitats and higher mortality in more mesic habitats could be the proximal factors leading to the patterns described. A few other factors might also explain the higher success of gallers in harsher habitats. First, galls may offer effective protection against the harsher climatic variation in dry habitats (Price et al. 1987; Fernandes and Price 1988; 1991). Second, the gall inducing larva is able to manipulate the host plant, even in habitats where plants usually exhibit a poor nutritional status, to obtain a food resource free of the high defensive compounds found in stressed or sclerophyllous host plants (Fernandes 1987; Nyman and Julkunen-Tiitto 2000; see also Oliveira et al. 2016). Third, the rate of attack by natural enemies and mortality caused by host plant resistance in harsher habitats is lower than mesic ones (Fernandes and Price 1992; Schultz 1992; Fernandes et al. 2005). All these factors suggest that host plants growing in habitats with poor soils under low humidity should be more susceptible to attack by galling insects (Fernandes et al. 2005; Julião et al. 2014a). Furthermore, synchronized resprouting induced by fire in some of these habitats may foster host-shifts and consequently galling insects attack (Mendonça 2001).

Despite the numerous studies on distribution patterns of insect galls in several vegetation types around the world, very few studies have been conducted in the mega diverse Amazonian rainforest (but see Almada and Fernandes 2011; Silva et al. 2011; Julião et al. 2014a,b). The terra firme forests in the Amazonian region can be divided into plateau, slope, and valley habitats differing in their soil physico-chemical characteristics and drainage patterns (Hodnett et al. 1997; Luizão et al. 2004). In such contrasting habitats, differences in terrain height and inclination are accompanied by clear changes in floristic composition and diversity (Costa et al. 2009; Laurance et al. 2010; Schietti et al. 2014), as well as effects on the local fauna (Menin et al. 2007; Oliveira et al. 2009; Cintra and Naka 2012). Previously, Silva et al. (2011) surveyed one Biological Dynamics of Forest Fragments

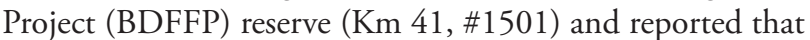
understory galling insect and host plant composition varied among terra firme plateau, slope, and valley; however, no difference was observed in galling insect richness among these habitats.

Terra firme forest habitats differ in topographic, edaphic, and hydrologic conditions. The water table is at greater depths in the plateaus, and approaches the surface towards the bottom of the valleys (Tomasella et al. 2007; Zanchi et al. 2011). Likewise, there is an increasing content of sand in the soil from plateau to valleys, with a corresponding decrease in clay content. A higher nutrient retention capacity has been observed in plateau habitats, while leaching rates are higher in slopes and valleys (Bravar and Righi 1988; Ribeiro et al. 1994). As a consequence, plateaus are drier, but relatively nutrient rich, while valleys are humid although relatively nutrient poor; slopes combine lower water and nutrient availability at the same time. Together these characteristics produce a gradient of water and nutritional stresses in the direction slope $>$ plateau-slope transition $>$ plateau $>$ valley. With this understanding, we tested whether the distribution of galling species within the Amazonian rainforest follows the same distribution patterns found for galling insect species in other biogeographical regions of the globe (e.g., Blanche and Westoby 1995; Cuevas-Reyes et al. 2003; Oyama et al. 2003). Hence, the aim of this study was to investigate galling species richness along a topographic gradient, consisting of slope, plateau-slope transition, plateau, and valley habitats in the Brazilian Amazon rainforest. We also evaluated the relationships among possible habitat-related effects driven by differential host plant richness, botanical families and/or species composition of galling species.

\section{MATERIALS AND METHODS}

\section{Study area}

The study was conducted in three experimental areas (Cabo Frio, Florestal, and $\mathrm{Km}$ 41) that belong to the Biological Dynamics of Forest Fragments Project (BDFFP) of the National Institute of Amazonian Research/INPA (Figure 1),

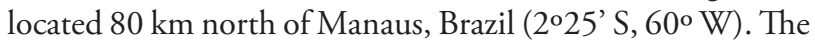
average annual temperature is $26^{\circ} \mathrm{C}$, the annual precipitation is $1,900-3,500 \mathrm{~mm}$, with the wet period occurring between December and May and the dry period between June and October (Laurance 2001). The local forest can be classified as dense lowland forest (Veloso et al. 1991) and is a terra firme forest, showing a canopy 30 - $37 \mathrm{~m}$ high (Luizão et al. 2004).

\section{Habitat description}

Terra firme forests exhibit a rugged topography composed of plateaus, slopes and valleys. These three environments 


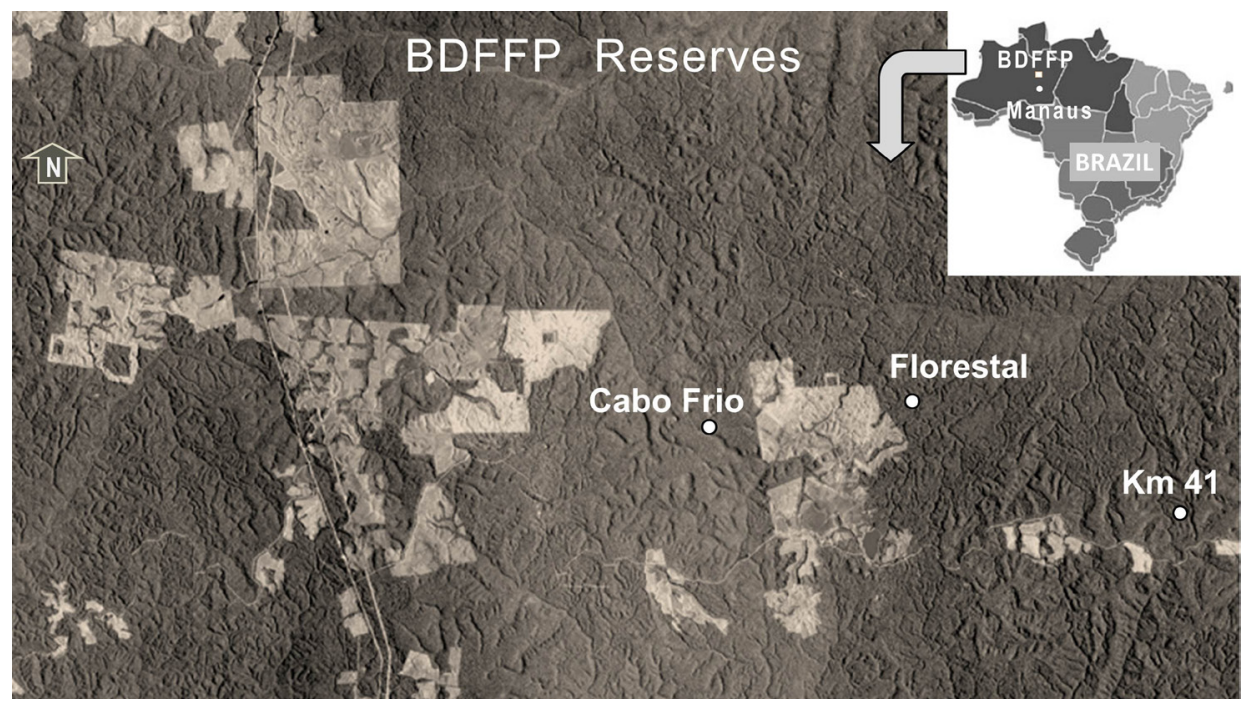

Figure 1. Location of the three BDFFP reserves (Cabo Frio, Florestal and $\mathrm{Km} 41$ ) where plateau, slope, plateau-slope transition, and valley habitats were sampled, in the central Amazon, Brazil. The color version of this figure is available in electronic edition only.

exhibit a gradient of soil texture and different drainage patterns (Bravard and Righi 1989; Luizão et al. 2004). Plateaus have the highest content of clay, which allows for a greater storage of nutrients and a well-developed forest canopy with emergent trees $(-45 \mathrm{~m})$. Slopes have an intermediate content of clay, which, along with their sloping terrain, results in a lower capacity for water retention; tree canopy ranges from 25 to 35 $\mathrm{m}$ high. Valleys, on the other hand, exhibit the highest sand content and have a superficial water table with low drainage and nutrient retention, lower plant biomass and trees with lower canopies of 20 to $35 \mathrm{~m}$. In this work, we also considered as "transition" the sloping areas between plateaus and slopes. These areas show intermediate conditions of clay content, soil drainage and plant species composition when compared to the plateaus and the slopes (Luizão et al. 2004; Zanchi et al. 2011). The steepness of the terrain is approximately 6 and 14 times greater in the slope habitat than in plateaus and valleys, respectively (Table 1).

\section{Insect gall survey}

Sampling was done in July 2004, during the rainy season. Nineteen plots ( 4 in valleys, 5 in slopes, 5 in plateau-slope transitions and 5 in plateau areas) that had been established for long-term studies (http://peld.inpa.gov.br/) were used for the evaluation of galling insect species richness. The minimum distance between the plots was $500 \mathrm{~m}$. Each plot measured $250 \times 3 \mathrm{~m}$ and a total area of $14,250 \mathrm{~m}^{2}$ was sampled. The longest axis of each plot followed an altitudinal isocline so that the variation in the soil characteristics could be minimized (Costa et al. 2005). In each plot, six inclination measurements were taken every $50 \mathrm{~m}$ along the longest axis of the plot with a clinometer over a $4 \mathrm{~m}$ strip perpendicular to the longest axis.
Table 1. Galling insect species richness (GIR) and characterization of plateau, slope, plateau-slope transition, and valley habitats of terra firme forest at the Biological Dynamics of Forest Fragments Project (BDFFP) reserves in the central Amazon.

\begin{tabular}{|c|c|c|c|}
\hline \multirow{2}{*}{ Habitat } & \multirow{2}{*}{ Soil type $†$} & Inclination $\left(^{\circ}\right)$ & GIR \\
\hline & & \multicolumn{2}{|c|}{ Average ( \pm Standard Deviation) } \\
\hline Plateau & $\begin{array}{l}\text { oxisols ( }>80 \% \text { clay) } \\
\text { ferrallitization process }\end{array}$ & $3.5(2.4)$ & $18.2(3.7)$ \\
\hline $\begin{array}{l}\text { Plateau-slope } \\
\text { transition }\end{array}$ & utisols ( $35-45 \%$ clay) & $10.6(2.2)$ & $20.0(5.4)$ \\
\hline Slope & utisols ( $21-42 \%$ clay) & $22.3(2.9)$ & $31.2(11.2)$ \\
\hline Valley & $\begin{array}{l}\text { spodosols ( } 2-6 \% \text { clay) } \\
\text { podzolization process } \\
\text { sandy soils }\end{array}$ & $1.5(1.0)$ & $6.0(1.8)$ \\
\hline
\end{tabular}

† Bravard and Righi 1988, 1989.

All vascular plants with heights between 1 and 3 meters (shrubs and saplings) were searched for the presence of galls induced by insects. Only host plants attacked by this guild were recorded and sampled. Leaves and branches with galls were stored in plastic bags and taken to the laboratory for description of insect gall morphospecies. Fruit, flower, and root galls were not detected in our study. The classification of galls into morphospecies was based on their external morphology (e.g., color, shape, and pubescence), location on the host plant, the organ affected and the host plant species (Fernandes and Price 1988). Usually, each insect species induces a characteristic kind of gall on only one organ of the host plant, and hence morphospecies of galls serve as a good surrogate for individual galling insect species (Carneiro et al. 2009). Host plant identification was done using a field guide of local flora (Ribeiro et al. 1999). 


\section{Statistical analyses}

Differences between habitats for inclination, galling insect species richness and host plant richness were assessed using Kruskal-Wallis tests with ties (Sprent and Smeeton 2007), followed by multiple comparisons by the minimal significant differences test (MSD), which adjust for multiple tests since potential differences might not be independent (Siegel and Castellan 1988). Due to unequal sampling effort among habitats, rarefied total species richness estimates of gall morphospecies was estimated taking into consideration plot samples (habitat replicates). These estimates were obtained by sample-based rarefaction performed with the BiodiversityR package (Kindt and Coe 2005). In this approach, expected richness is calculated based on the $n$ samples randomly sorted from the representative set of samples, and performing all possible sample combinations from the dataset. The analytical process involves no sample ordering or replacement, and advantageously preserves spatial patterns of distribution, such as species aggregation or segregation (Gotelli and Colwell 2010). Habitat-related differences in the gall species composition were analysed using presence/absence data in a Permutational Multivariate Analysis of Variance (PERMANOVA) and a Permutational Analysis of Multivariate Dispersions (PERMDISP) in tandem. Nonmetric multidimensional scaling (NMDS) plots were employed to depict gall species composition dissimilarities among habitats. All analyses were performed in the $\mathrm{R}_{3.2 .1}$ environment (R Development Core Team 2015).

\section{RESULTS}

A total of 5,360 individual plants were inspected for galls with approximately $10 \%$ having been attacked. Overall, 228 galling species on 169 host plant species were recorded; the plants were distributed among 38 botanical families (Supplementary Material, Table S1). The greatest richness of galling insects were on Fabaceae (12.3\%) and Burseraceae $(12.3 \%)$, followed by Chrysobalanaceae (9.2\%), and Sapotaceae (8.3\%) (Figure 2). Most galls were green, discoid and on leaves, while only $10 \%$ had trichomes on their external walls (see Supplementary Material, Table S1).

Terrain inclination varied among habitats $(\mathrm{H}=15.8$, df $=3, p=0.001)$, except for the comparison of plateau and valley (MSD, $3.5 \approx 1.5 ; \mathrm{p}>0.05$ ). Average inclination of slope habitats was approximately 6 and 14 times greater than in plateaus and valleys, respectively (Table 1 ). The number of galling insect species was on average 1.7 and 5.2 times higher on slopes than on plateaus and valleys, respectively (Table 1), and these differences among habitats were significant $(\mathrm{H}=$ 13.7, $\mathrm{df}=3, \mathrm{p}=0.003)$. All multiple comparisons showed significant differences, except for the plateau-transition comparison (MSD, 18.2 $\approx 20.0 ; \mathrm{p}>0.05$; Figure $3 \mathrm{~A}$ ). The average number of galling species increased with terrain inclination such that galling insect richness increased in the direction of valley-plateau-transition-slope (Figure 3A). The same pattern of gall richness was observed when the sampling effort was controlled in rarefaction curves based on the number of plots (Figure 4).

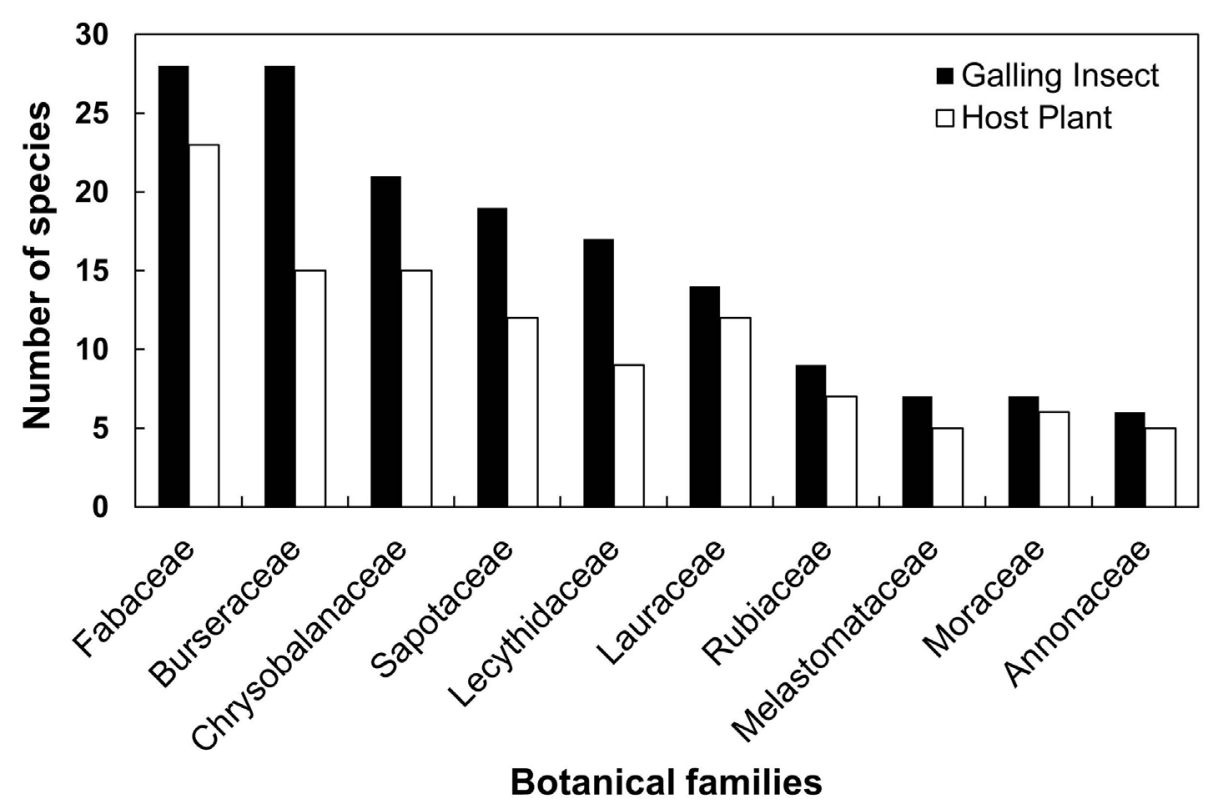

Figure 2. Insect gall morphospecies richness and the number of host plant species of the ten most frequent botanical families at the BDFFP reserves in the central Amazon. 

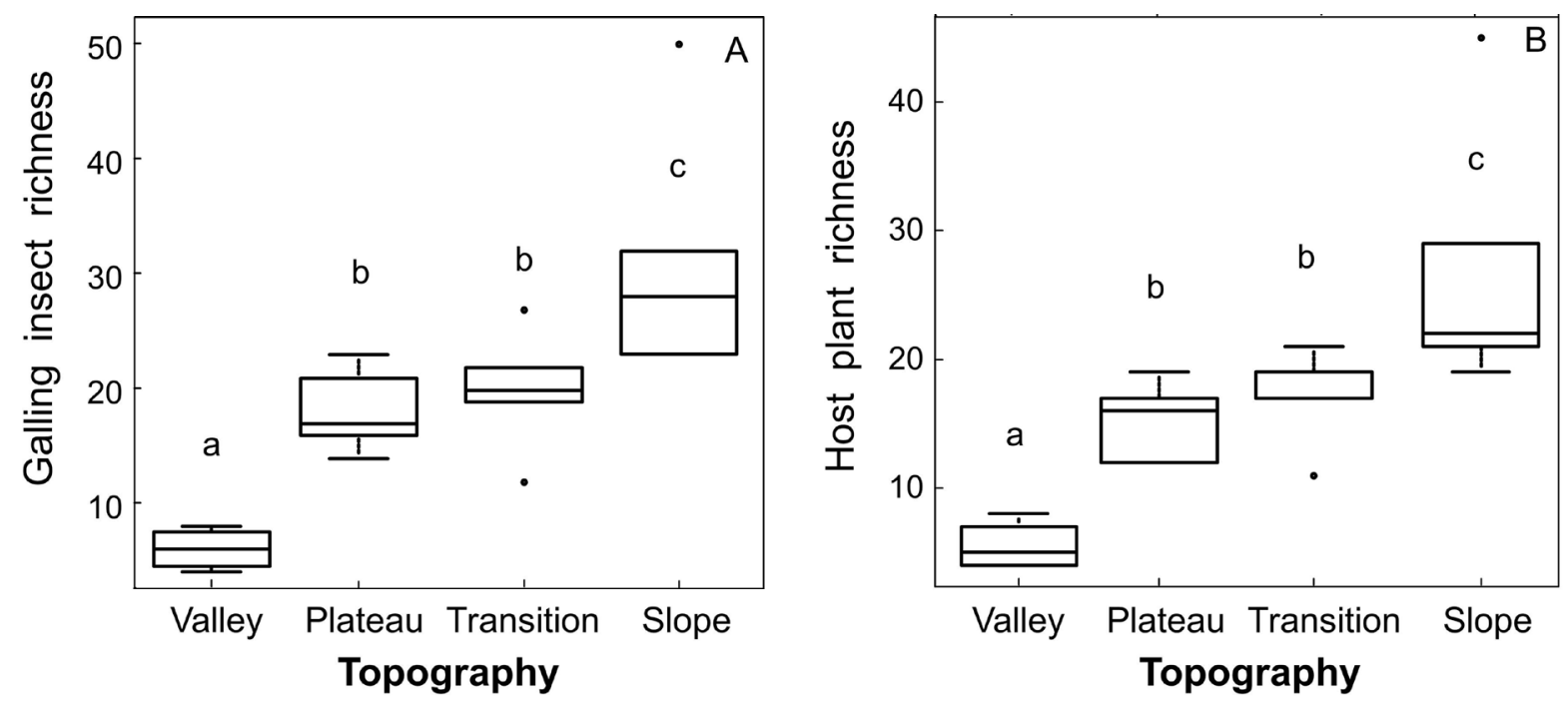

Figure 3. Box plot (based on the median and interquartile range) showing galling insect species/GIR (A) and host plant/HPR (B) richness along a topographic gradient - plateau, plateau-slope transition, slope, and valley - in the BDFFP reserves, central Amazon. GIR values differed among habitats; all multiple comparisons showed significant differences, except for the plateau-transition pairwise comparison (MSD, minimal significant differences test, 18.2 $\approx 20.0 ; p>0.05$ ). HPR values differed among habitats; all multiple comparisons showed significant differences, except for the plateau-transition pairwise comparison (MSD, $15.2 \approx$ $17.0 ; p>0.05)$. Habitats with same letters did not differ significantly after a Kruskal-Wallis test followed by a MSD.

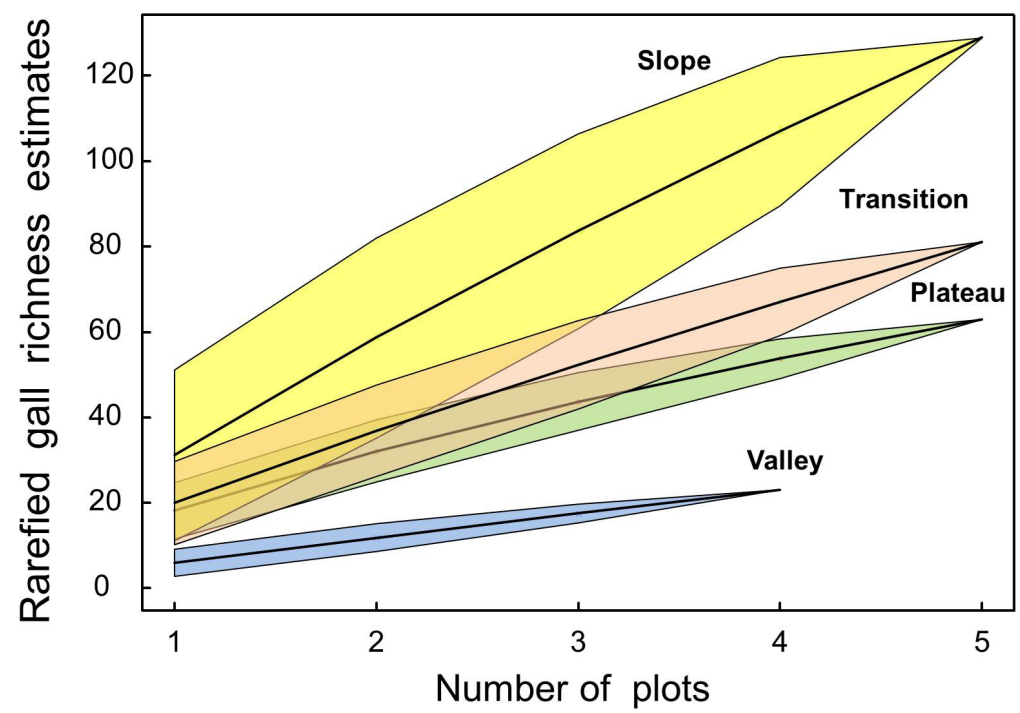

Figure 4. Species accumulation curves (SAC) of gall insect species surveyed in the topographic gradient - plateau, plateau-slope transition, slope, and valley in the BDFFP reserves, central Amazon. Bold lines depict rarefied samples (plots) and colored areas represent their $95 \%$ confidence interval. The color version of this figure is available in electronic edition only.

Host plant richness also differed among habitats $(\mathrm{H}=14.2$, $\mathrm{df}=3, \mathrm{p}=0.003$ ), being highest on slopes (average richness per plot: 27.2; Figure 3B). There was no significant difference in host plant richness between plateau and transition habitats. The number of galling insect species per host plant species did not vary significantly among habitats $(\mathrm{H}=1.7, \mathrm{df}=$ $3, p=0.627$ ), suggesting that (i) host plant species at the understory harbor similar number of galling insect species, independently of habitat and/or (ii) few superhosts in the understory vegetation.

PERMANOVA analysis (pseudo- $\mathrm{F}_{3,15}=1.58, \mathrm{P}=0.001$, Table 2) and NMDS ordination plot (Figure 5) demonstrated that the gall species composition differed significantly among 
Table 2. PERMANOVA and PERMDISP results of Sørensen dissimilarities for gall-forming insect assemblage structure in relation to terra firme habitats (Slope, Transition, Valley, and Plateau). Abbreviations: $\mathrm{df}=$ degrees of freedom, $\mathrm{SS}=$ sum of squares, $\mathrm{MS}=$ mean sum of squares, $p$ seudo $-\mathrm{F}=\mathrm{F}$ value obtained by 999 permutations.

\begin{tabular}{lccccccc}
\hline Permutational Analysis & Source & $\mathrm{df}$ & $\mathrm{SS}$ & $\mathrm{MS}$ & pseudo-F & $\mathrm{R} 2$ & $\mathrm{P}$ \\
\hline Multivariate & Habitat & 3 & 1.7773 & 0.5924 & 1.5864 & 0.2408 & 0.001 \\
Variance & Residuals & 15 & 5.6016 & 0.3734 & & 0.7591 & \\
(PERMANOVA) & Total & 18 & 7.3789 & & & 1.0000 & \\
\hline Multivariate & Habitat & 3 & 0.0294 & 0.0098 & 7.0437 & 0.006 \\
beta-dispersion & Residuals & 15 & 0.0208 & 0.0014 & & & \\
(PERMDISP) & & & & & & & \\
\hline
\end{tabular}

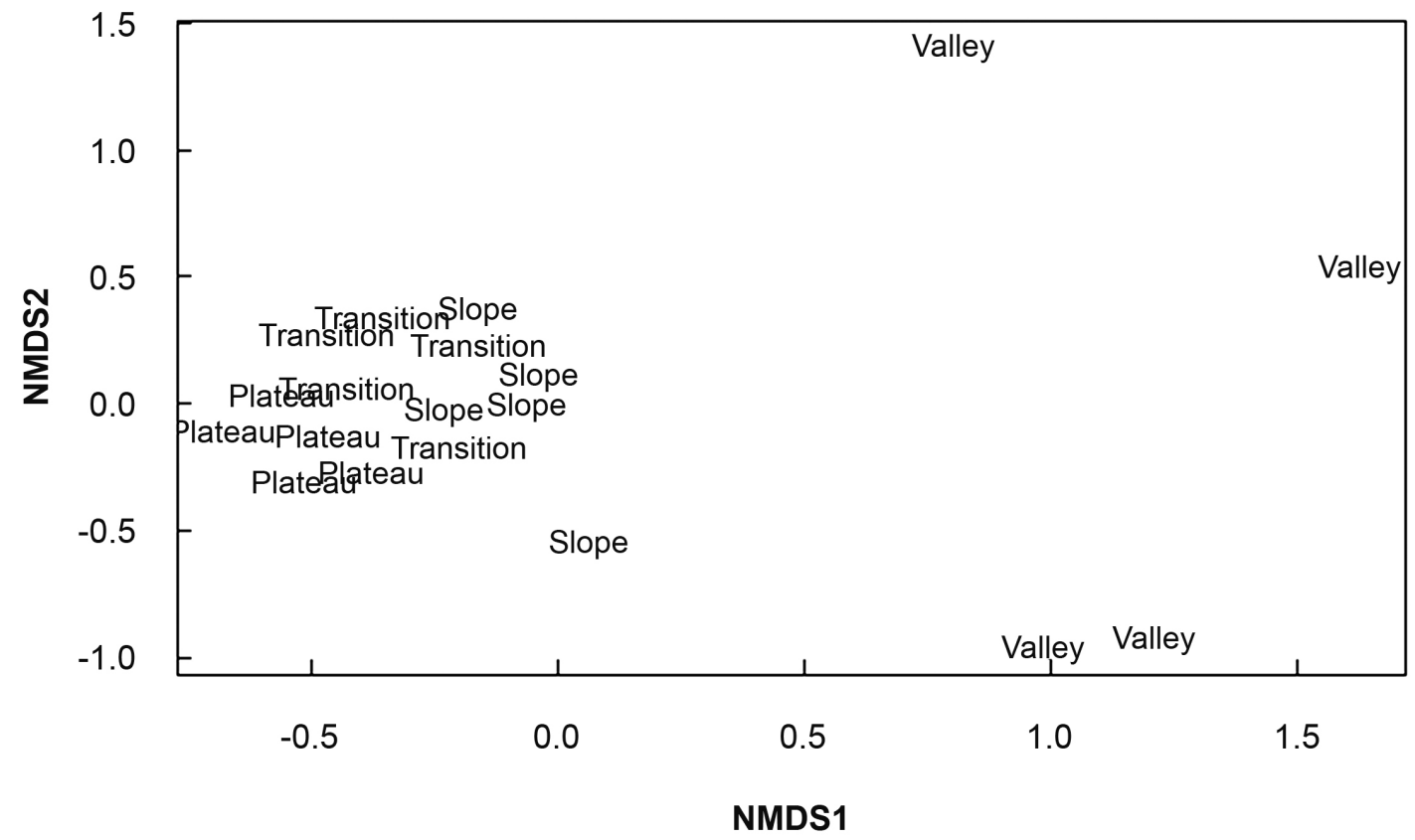

Figure 5. Nonmetric multidimensional scaling (NMDS; isoMDS() with Jaccard distance - Vegan package in R software) graph for dissimilarities in the galling insect species composition of the 19 sampling plots $(250 \times 3 \mathrm{~m})$ at the plateau, slope, plateau-slope transition, and valley habitats, central Amazon, Brazil.

habitats. However, a significant PERMDISP result suggested that these structural differences in species composition were due to unequal dispersion of variability among forest habitats (pseudo- $\mathrm{F}_{3,15}=7.04, \mathrm{P}=0.006$, Table 2 ), probably related to (small scale) spatial heterogeneity.

\section{DISCUSSION}

We observed a greater richness of host plants and galling insects in the slope habitat of Amazonian terra firme forests than in the other topographic habitats. This finding suggests that insect galls are favored in stressful environments, since slopes are comparatively the most stressful habitat within Amazonian terra firme forests. Slope habitats have the lowest levels of water and nutrients compared to the other habitats studied (Zanchi et al. 2011). A study by Luizão et al. (2004) indicated that slope and plateau habitats presentes higher nitrogen levels in their living leaves, litter and soil upper layer than that observed in the valleys, while carbon concentration in the vegetation samples did not vary among these habitats, therefore resulting in a high C:N ratio in valley habitat. However, further studies should encompass direct measures of specific nutrients in the host and non-host plants.

Our results also suggest that nutritional (soil fertility) and hygrothermic (habitats in the topographic gradient) conditions influence the number of species that are potential hosts in each habitat. The main factor that influenced galling insect species richness at the scale of this study was vegetation diversity and composition. Plateaus support a greater biomass of arboreal plants while slope and valley 
habitats predominantly have greater Arecaceae biomass, which includes palm lianas, shrubs, and trees (Castilho et al. 2006). Topographic gradients have also been shown to explain the variation in the species composition of palms (Rodrigues et al. 2014), as well as variation in the species richness and density of herbs and pteridophytes (Costa 2006). The importance of plant species richness in determining galling insect species richness has also been indicated in several previous studies (e.g., Fernandes and Price 1988, 1991, Fernandes 1992, Araújo et al. 2013).

The galling insect communities in the habitats of this study were, via host plant diversity, strongly influenced by variation in soil characteristics and water status. Hence, plant species zonation, richness, and composition in Amazonian forest types seem to represent important explanatory variables for the pattern of galling insect species richness observed among habitats (Fernandes 1992; Veldtman and McGeoch 2003; Julião et al. 2014b). While significant differences in the number of tree species between different habitats were not found in Amazonian terra firme forests, differences in taxonomic composition was consistently reported by Kahn and Castro (1985), Oliveira (1997), Oliveira and Amaral (2004), Ribeiro et al. (1999), Valencia et al. (2004) and by Silva et al. (2014). Future studies should examine variation in taxonomic composition of plants and its relationship to variation in galling insect species richness in the understory of Amazonian terra firme forests. Another alternative explanation for the differences in galling richness among terra firme habitats is related to bottom-up (via host plant), and top-down (via natural enemies) factors that could result in different mortality rates (Fernandes 1998; Fernandes et al. 2003; Juliáo et al. 2014b). Unfortunately, we are not aware of any study dealing with the proximate causes of galling insect mortality in Amazonian forest types (but see Fernandes et al. 2012).

Although we recorded 228 galling species, the actual richness is probably much higher since samples were conducted only in the understory of the forest. Price et al. (1998), for example, reported a very low number of galling insect species for a small area in the Amazonian forest near Manaus and another one near Porto Velho (Rondônia), while Yukawa et al. (2001) reported a high number of galling species near Manaus. In the eastern Amazon, three surveys conducted in the region of Porto Trombetas also recorded a high diversity of galling insects in the understory habitat. Maia (2011) obtained 78 galling species whereas Almada and Fernandes (2011) and Araújo et al. (2012) sampled 309, and 112 galling insect morphospecies, respectively, in the same study area. The discrepancies among these findings may be the result of samplings being performed in forest stands at different succession stages (Price 2005) and using differing methodologies. Silva et al. (2011) also sampled galling insects and host plants in plateau, slopes, and valley habitats plus campinarana habitats (sclerophyllous vegetation growing on sandy soils) in the central Amazon of Brazil. They found $35(3 \%)$ out of 1,200 surveyed individual plants to have been attacked by 27 galling insect species. In our study, the percentage of attacked plants was ca. threefold higher (10\%) than reported by Silva et al. (2011), which can be explained by differences in sampling effort (this study: 5,360 plants) and by sampling team experience (Dalbem and Mendonça 2006).

The most attacked plant families in the studied sites were the families most represented in the Amazonian rain forest: Fabaceae, followed by Burseraceae, Chrysobalanaceae, and Sapotaceae. The taxon with the highest number of host plants in this study (Fabaceae -23 species) also had the highest richness of galling species (28 morphospecies). The same pattern has been reported for the Brazilian savanna (Cerrado) by Gonçalves-Alvim and Fernandes (2001), rupestrian grasslands (Lara et al. 2002; Maia and Fernandes 2004), and the Atlantic Forest (Fernandes et al. 2001), where the most represented botanical families had greater richness of galling species. This pattern may be a general one since it was also reported for tropical rainforests of Indonesia (Fernandes and Lara 1993) and woodland Australian sites with Mediterranean climate (Blanche 1994) (for a review see Fernandes 1992). However, Rubiaceae (genera Palicourea and Psychotria) and Melastomataceae (genus Miconia) have also been recorded as important host plant taxa to galling insects in the eastern Amazon at Porto Trombetas in the state of Pará, Brazil (Almada and Fernandes 2011; Maia 2011; Silva et al. 2011).

\section{CONCLUSIONS}

This study provides support to the hypothesis that stressful habitats within Amazonian terra firme forests have higher richness of gall inducing insects, and that this richness could be mediated by an increased number of host plants. Besides, the differential gall species composition seems to be associated with a fine-scale spatial heterogeneity - local mosaic of water status and nutrient availability resulting from the topographic conditions - in which host plants, galling insects, and their interactions are affected. Future studies should attempt to experimentally address the influence of water and nutritional stress on galling insect species physiology, as well as the role of natural enemies and plant physiological conditions in galling performance and success.

\section{ACKNOWLEDGMENTS}

We thank TG Cornelissen and two anonymous reviewers for suggestions on earlier versions of the manuscript. We thank INPA (Instituto Nacional de Pesquisas da Amazônia), Smithsonian Institution and to Biological Dynamics of Forest Fragments Project for logistical support, Graduate program in 
Ecology, Conservation and Management of Wildlife - UFMG and CNPq. A scholarship was provided to ED Almada by CNPq. We thank AE Santos for assistance in the field and AC Castilho for help with plant identification.

\section{REFERENCES}

Almada, E.D.; Fernandes, G.W. 2011. Insetos indutores de galhas em florestas de terra firme e em reflorestamentos com espécies nativas na Amazônia Oriental, Pará, Brasil. Boletim do Museu Paraense Emilio Goeldi, 6: 163-196.

Araújo, W.S.; Porfírio-Júnior, E.D.; Jorge, V.A. et al. 2012. Plantas hospedeiras e galhas entomógenas em sub-bosques de florestas tropicais do Pará, Brasil. INSULA Revista de Botânica, 41: 59-72.

Araújo, W. S.; Scareli-Santos, C.; Guilherme, F. A. G.; \& CuevasReyes, P. 2013. Comparing galling insect richness among Neotropical savanas: effects of plant richness, vegetation structure and super-host presence. Biodiversity and Conservation, 22: 1083-1094.

Blanche, K.R. 1994. Insects Induced galls on Australian Vegetation, In: Price, P.W.; Mattson, W.J.; Baranchikov, Y. (Ed.). Gallforming insects: ecology, physiology and evolution. General Technical Report NC-. Forest Service, North Central Research Station, USA, p. 49-55.

Blanche, K.R.; Westoby, M. 1995. Gall-forming insect diversity is linked to soil fertility via host plant taxon. Ecology, 76: 2334-2337.

Bravard, S.; Righi, D. 1988. Characteristics of clays in an OxisolSpodosol toposequence in Amazonia (Brazil). Clay Minerals, 23: 279-289.

Bravard, S.; Righi, D. 1989. Geochemical differences in an OxisolSpodosol toposequence of Amazonia, Brazil. Geoderma, 44: $29-42$.

Carneiro, M.A.A.; Branco, C.S.A.; Braga, C.E.D.; Almada, E.D.; Costa, M.B.M.; et al. 2009. Are gall midge species (Diptera: Cecidomyiidae) host plant specialists? Revista Brasileira de Entomologia, 53: 365-378.

Castilho, C.V.D.; Magnusson, W.E.; de Araújo, R.N.O.; Luizão, R.C.C.; Luizão, F.J.; Lima, A.P.; Higuchi, N. 2006. Variation in aboveground tree live biomass in a central Amazonian Forest: Effects of soil and topography. Forest Ecology and Management, 234: 85-96.

Cintra, R.; Naka, L.N. 2012. Spatial Variation in Bird Community Composition in Relation to Topographic Gradient and Forest Heterogeneity in a Central Amazonian Rainforest. International Journal of Ecology, doi:10.1155/2012/435671.

Costa, F.R.C. 2006. Mesoscale Gradients of Herb Richness and Abundance in Central Amazonia. Biotropica, 38: 711-717.

Costa, F.R.C.; Magnusson, W.E.; Luizão, R.C. 2005. Mesoscale distribution patterns of Amazonian understorey herbs in relation to topography, soil and watersheds. Journal of Ecology, 93: 863-878.

Costa, F.R.C.; Guillaumet, J.L.; Lima, A.P.; Pereira, O.S. 2009. Gradients within gradients: the mesoscale distribution patterns of palms in a central amazonian forest. Journal of Vegetation Science, 20: 69-78.
Cuevas-Reyes, P.; Siebe, C.; Martinez-Ramos, M.; Oyama, K. 2003. Species richness of fall-forming insects in a tropical rain forest: correlations wiht plant diversity and soil fertility. Biodiversity \& Conservation, 12: 411-422.

Dalbem, R.V.; Mendonça, M.S. 2006. Diversity of galling arthropods and host plants in a subtropical forest of Porto Alegre, Southern Brazil. Neotropical Entomology, 35: 616-624.

Fernandes, G.W. 1987. Gall forming insects: their economic importance and control. Revista Brasileira de Entomologia, 31: 379-398.

Fernandes, G.W. 1992. Plant family size and age effects on insular gall-forming species richness. Global Ecology and Biogeography Letters, 2: 71-74.

Fernandes, G.W. 1998. Hypersensitivity: a phenotypic basis of plant resistance against herbivory. Environmental Entomology, 27: 260-267.

Fernandes, G.W.; Price, P.W. 1988. Biogeographical gradients in galling species richness. Oecologia, 76: 161-167.

Fernandes, G.W.; Price, P.W. 1991. Comparisons of tropical and temperate galling species richness: the role of environmental harshness and plant nutrient status. In: Price, PW; Lewinsohn, TM; Fernandes, GW; Benson, WW (Ed.). Plant-animal interactions: evolutionary ecology in tropical and temperate regions, John Wiley, New York, USA, p. 91-116.

Fernandes, G.W.; Price, P.W. 1992. The adaptive significance of insect gall ditribution: surviorship in xeric and mesic habitat. Oecologia, 90: 14-20.

Fernandes, G.W.; Lara, A.C.F. 1993. Diversity of Indonesian gallforming herbivores along altitudinal gradients. Biodiversity Letters 1: 186-192.

Fernandes, G.W.; Julião, G.R.; Araújo, R.C. et al. 2001. Distribution and morphology of insect galls of the Rio Doce Valley, Brazil. Naturalia, 26: 211-244.

Fernandes, G.W.; Duarte, H.; Lüttge, U. 2003. Hypersensitivity of Fagus sylvatica L. against leaf galling insects. Trees, 17: 407-411.

Fernandes, G.W.; Gonçalves-Alvim, S.J.; Carneiro, M.A.A. 2005. Habitat-driven effects on the diversity of gall-inducing insects in the Brazilian Cerrado Biology, ecology and evolution of gall-inducing arthropods. In: Raman, A.; Schaefer, C.W.; Withers, T.M. (Ed.). Biology, Ecology, and evolution of gall-inducing arthropods. Science Publishers, Inc., Enfield (NH) USA, p. 693-708.

Fernandes, G.W.; Santos, J.C.; Gomes, V.M. 2012. Misleading herbivory in a tropical tree. Arthropod-Plant Interactions, 6: 649-654.

Gonçalves-Alvim, S.J.; Fernandes, G.W. 2001. Comunidades de insetos galhadores (Insecta) em diferentes fisionomias do cerrado em Minas Gerais, Brasil. Revista Brasileira de Zoologia, 18: 289-305.

Gotelli, N.J.; Colwell, R.K. 2010. Estimating species richness. In: Magurran, A.E.; McGill, B.J. (Ed.). Frontiers in measuring biodiversity. Oxford University Press, New York, p.39-54.

Hodnett, M.G.; Vendrame, I.; Marques Filho, A.O.; Oyama, M.D.; Tomasella, J. 1997. Soil water storage and groundwater behavior in a catenary sequence beneath forest in central Amazonia: I. 
Comparisons between plateau, slope and valley floor. Hydrology and Earth System Sciences, 1: 265-277.

Juliāo, G.R.; Venticinque, E.M.; Fernandes, G.W. 2005. Richness and abundance of gall-forming insects in the Mamirauá Varzea, a flooded Amazonian forest. Uakari, 1: 39-42.

Julião G.R.; Almada, E.D.; Fernandes, G.W. 2014a. Galling insects in the Pantanal wetland and Amazonian rainforest. In: Fernandes, G.W.; Santos, J.C. (Ed.). Neotropical Insect Galls. Springer Science, Dordrecht, p.377-403.

Juliāo, G.R.; Venticinque, E.M., Fernandes, G.W.; Price, P.W. 2014 b. Unexpected high diversity of galling insects in the Amazonian upper canopy: the savanna out there. PLoS ONE, 9: e114986. doi:10.1371/journal.pone.0114986.

Kahn, F.; Castro, A. 1985. The palm community in a forest of central Amazonia, Brazil. Biotropica, 17: 210-216.

Kindt, R.; Coe, R. 2005. Tree diversity analysis: A manual and software for common statistical methods for ecological and biodiversity studies.

Lara, A.C.F.; Fernandes, G.W.; Gonçalves-Alvim, S.J. 2002. Tests of hypotheses on patterns of gall distribution along an altitudinal gradient. Tropical Zoology, 15: 219-232.

Laurance, W.F. 2001. The hyper-diverse flora of the central Amazon: an overview. In: Bierregaard, R.O.; Gascon, C.; Lovejoy, T.E.; Mesquita, R. (Ed.). Lessons from Amazonia: Ecology and Conservation of a Fragmented Forest. Yale University Press, New Haven, Connecticut, USA, p.47-53.

Laurance, S.G.; Laurance, W.F.; Andrade, A.; Fearnside, P.M.; Harms, K.E.; Luizáo, R. 2010. Influence of soils and topography on Amazonian tree diversity: a landscape-scale study. Journal of Vegetation Science, 21: 96-106.

Luizão R.C.C.; Luizão F.J.; Paiva, R.Q.; Monteiro, T.F.; Sousa, L.S.; Kruijt, B. 2004. Variation of carbon and nitrogen cycling processes along a topographic gradient in a central Amazonian forest. Global Change Biology, 10: 592-600.

Maia, V.C.; Fernandes, G.W. 2004. Insect galls from Serra de São José (Tiradentes, MG, Brazil). Brazilian Journal of Biology, 6: 423-445.

Maia, V.C. 2011. Characterization of insect galls, gall makers, and associated fauna of Platô Bacaba (Porto de Trombetas, Pará, Brazil). Biota Neotropica, 11:37-53.

Mendonça Jr., M.D. 2001. Galling insect diversity patterns: the resource synchronization hypothesis. Oikos, 95: 171-176.

Menin, M.; Lima, A.P.; Magnusson, W.E.; Waldez, F. 2007. Topographic and edaphic effects on the distribution of terrestrially reproducing anurans in Central Amazonia: mesoscale spatial patterns. Journal of Tropical Ecology, 23: 539-547.

Nyman, T; Julkunen-Tiitto, R. 2000. Manipulation of the phenolic chemistry of willows by gall-inducing sawflies. Proceedings of the National Academy of Science of the United States of America 97: 13184-13187.

Oliveira, A.A. 1997. Diversidade, estrutura e dinâmica do componente arbóreo de uma floresta de terra firme de Manaus, Amazonas. PhD Thesis, Universidade de Sáo Paulo.
Oliveira, A.N.; Amaral, I.L. 2004. Florística e fitossociologia de uma floresta de vertente na Amazônia Central, Amazonas, Brasil. Acta Amazonica, 34: 21-34.

Oliveira, P.Y.; Souza, J.L.P.; Baccaro, F.B.; Franklin, E. 2009. Ant diversity distribution along a topographic gradient in a central Amazonian terra-firme forest reserve. Pesquisa Agropecuária Brasileira, 44: 852-860.

Oliveira, D.C.; Isaias, R.M.S.; Fernandes, G.W.; Ferreira, B.G.; Carneiro, R.G.S.; Fuzaro, L. 2016. Manipulation of host plant cells and tissues by gall-inducing insects and adaptive strategies used by different feeding guilds. Journal of Insect Physiology 84: 103-113. http://dx.doi.org/10.1016/j.jinsphys.2015.11.012

Oyama, K.; Perez-Perez, M.A.; Cuevas-Reyes, P.; Luna-Reyes, R. 2003. Regional end local species richness of gall-inducing insects in two tropical rain forest in México. Journal of Tropical Ecology, 19: 595-598.

Price, P.W. 2005. Adaptive radiation of gall-inducing insects. Basic and Applied Ecology, 6: 413-421.

Price, P.W.; Fernandes, G.W.; Waring, G.L. 1987. Adaptative nature of insect galls. Environmental Entomology, 16: 15-24.

Price, P.W.; Fernandes, G.W.; Lara, A.C.; et al. 1998. Global patterns in local number of insect galling species. Journal of Biogeography, 25: 581-591.

R Development Core Team. 2015. R: A language and environment for statistical computing. R Foundation for Statistical Computing, Vienna, Austria. ISBN 3-900051-07-0, URL http://www.Rproject.org/.

Ribeiro-Mendes, H.N.; Marques, E.S.A.; Silva, I.M.; Fernandes, G.W. 2002. Influence of host-plant sex and habitat on survivorship of insect galls within the geographical range of the host-plant. Tropical Zoology, 15: 5-15.

Ribeiro, J.E.L.S.; Hopkins, M.J.G.; Vicentini, A.; et al. 1999. Flora da Reserva Ducke; guia de identificação das plantas vasculares de uma floresta de terra-firme na Amazonia Central. INPA -DFID, Manaus, Brazil.

Ribeiro, J.E.L.S.; Nelson, B.W.; Silva, M.F.F.; Martins, L.S.S.; Hopkins, M. 1994. Reserva Florestal Ducke: Diversidade e composição da flora vascular. Acta Amazonica, 24: 19-30.

Rodrigues, L.F.; Cintra, R.; Castilho, C.V.; Pereira, O.S.; Pimentel, T.P. 2014. Influences of forest structure and landscape features on spatial variation in species composition in a palm community in central Amazonia. Journal of Tropical Ecology, 30, 565-578 doi:10.1017/S0266467414000431

Schietti, J., Emilio, T., Rennó, C.D.; Drucker, D.P.; Costa, F.R.C.; Nogueira, A. et al. 2014. Vertical distance from drainage drives floristic composition changes in an Amazonian rainforest. Plant Ecology \& Diversity, 7: 241-253. doi: 10.1080/17550874.2013.783642

Schultz, B.B. 1992. Insect herbivores as potential causes of mortality and adaptation in gall-forming insects. Oecologia, 90: 297-299.

Siegel, S.; Castellan, N.J. 1988. Nonparametric Statistics for the Behavioral Sciences. McGraw-Hill Inc., New York, USA, 2nd ed.

Silva, K.E.; Martins, S.V.; Fortin, M.J.; et al. 2014. Tree species community spatial structure in a terra firme Amazon forest, Brazil. Bosque, 35: 347-355. 
Silva, P.; Almeida-Santos, B.; Tabarelli, M.; Almeida-Cortez, J. 2011. Occurrence of gall complexes along a topographic gradient in an undisturbed lowland forest of central Amazonia. Revista Brasileira de Biociências, 9: 133-138.

Sprent, P.; Smeeton, N.C. 2007. Applied Nonparametric Statistical Methods. Chapman and Hall, Boca Raton, USA, 4th ed.

Tomasella, J.; Hodnett, M.G.; Cuartas, L.A.; Nobre, A.D.; Waterloo, M.J.; Oliveira, S.M. 2007. The water balance of an Amazonian micro-catchment: The effect of interannual variability of rainfall on hydrological behavior. Published online, Hydrological Processes.

Valencia, R.; Foster, R.B.; Villa, G.; et al. 2004. Tree species distribuition and local variation in the Amazon: large forest plot in eastern Ecuador. Journal of Ecology, 92: 214-229.

Veldtman, R.; McGeoch, M.A. 2003. Gall-forming insect species richness along a non-scleromorphic vegetation rainfall gradient in South Africa: the importance of plant community composition. Austral Ecology, 28: 1-13.

Veloso, H.P.; Rangel-Filho, A.L.R.; Lima, J.C.A. 1991. Classificação da vegetação brasileira, adaptada a um sistema universal. IBGE, Departamento de Recursos Naturais e Estudos Ambientais, Rio de Janeiro, Brasil.

Yukawa, J.; Tokuda, M.; Uechi, N.; Sato, S. 2001. Species richness of galling arthropods in Manaus, Amazon and the surroundings of the Iguassu Falls. Esakia, 41: 11-15.
Zanchi, F.B.; Waterloo, M.J.; Dolman, A.J.; Groenendijk, M.; Kesselmeier, J.; Kruijt, B.; Bolson, M.A.; Luizão, F.J.; Manzi, A.O. 2011. Influence of drainage status on soil and water chemistry, litter decomposition and soil respiration in central Amazonian forests on sandy soils. Ambiente \& Água, 6: 6-29.

Received: $10 / 03 / 2017$

Accepted: 13/06/2017

\section{SUPPLEMENTARY MATERIAL}

(only available in the electronic version).

JULIÃO et al. Understory host plant and insect gall diversity changes across topographic habitats differing in nutrient and water stress in the Brazilian Amazon rainforest.

Table S1. Morphological description of each insect gall morphospecies, host species and botanical families sampled in the understory of three reserves (Cabo Frio, Florestal, and Km 41) of the Biological Dynamics of Forest Fragments Project (BDFFP), National Institute of Amazonian Research/INPA. 